\title{
ПРОДУКТИВНОЕ ДОЛГОЛЕТИЕ ЖИВОТНЫХ, СПОСОБЫ ЕГО ПРОГНОЗИРОВАНИЯ И ПРОДЛЕНИЯ
}

\author{
(обзор)
}

\section{B.A. БЕКЕНЁВ}

Удлинение сроков продуктивного использования животных - важнейшая проблема в разведении молочного и молочно-мясного скота, свиноводстве и других отраслях животноводства. Целью настоящей работы стал обзор влияния различных генотипических и паратипических факторов на продолжительность жизни, продуктивное долголетие поголовья, а также анализ способов их прогнозирования и продления. Показано, что с увеличением удоя за лактацию с 2500-3000 до 10000 кг продолжительность продуктивного использования коров снижается с 7-9 до 2-3 лактаций, что повышает себестоимость производства молока (И.И. Клименок с соавт., 2001; J.R. Wright с соавт., 2016 и др.). Увеличение молочной продуктивности сопровождается снижением воспроизводительной функции: удлиняется сервис-период, снижается оплодотворяемость, что вызвано стрессом в результате активации лактационной доминанты (А.И. Абилов с соавт., 2013; Y.C. Schuermann coавт., 2016). Для улучшения воспроизводительной функции и продолжительности использования рекомендуется применять специальные минерально-витаминные добавки (Л.В. Романенко с соавт., 2014; Б. Клоуз, 2007). Благополучие животных рассматривают как показатель устойчивости системы и считают экономически выгодным (Р.A. Oltenacu с соавт., 2010; Л.В. Ефимова с соавт., 2017). Продолжительность продуктивного использования свиноматок, зависящая от количества опоросов за период использования, многоплодия, выживаемости поросят и других факторов, составляет 3-4 опороса вместо 4,5 по принятой норме, что также отражается на экономических показателях (M.D. Ноge с соавт., 2011). Приводятся показатели наследуемости признаков долголетия у крупного рогатого скота и свиней (L. Canario с соавт., 2006), различные способы кормления, селекционные приемы, в том числе применение генетических маркеров для удлинения хозяйственного использования животных (C.N. Lopes c coaвт., 2011; A.I. Sironen c соавт., 2010). Приведены молекулярные маркеры, связанные с репродуктивными особенностями и продолжительностью использования животных, которые следует применять и в геномной селекции (Н.С. Юдин с соавт., 2015; Q. Zhang с соавт., 2017 и др.). Рассмотрены теоретические положения о причинах старения, влиянии различных стрессоров, возникающих при этом перекисных и антиокислительных процессах в организме (Э.С. Бауэр, 1935; В.Л. Воейков, 2002). Обсуждается роль активных форм кислорода, свободных радикалов и антиоксидантов разной природы на воспроизводительную функцию и жизнеспособность животных при стрессовых воздействиях разной силы (D.D. Boler с соавт., 2012; M. Sajeda Eidan, 2016). Для увеличения сроков продолжительности использования и долголетия сельскохозяйственных животных в сочетании с высокой продуктивностью и приспособленностью к различным, в том числе неблагоприятным, факторам внешней среды следует использовать методы, складывающиеся из нескольких позиций. Необходимо разрабатывать и использовать приемы полноценного кормления, оптимизирующие энергетический баланс во все периоды репродуктивного цикла, создавать благоприятные условия содержания животных, предусматривающие воздействие на них определенными стимулирующими факторами, которые повышают биофизический потенциал организма. Следует также использовать новейшие методы прогнозирования степени свободно-радикального окисления липидов тканей животных, влияющих на проявление охоты, жизнеспособность яйцеклеток и сперматозоидов, и применять антиоксиданты с кормовыми добавками для сбалансированности окислительных и антиоксидантных процессов. Можно создавать стада (породы, типы) животных, обладающих высоким генетическим потенциалом продуктивности и стрессоустойчивости с помощью наиболее эффективных приемов селекции, генетических маркеров, генетико-математических моделей, генно-инженерных методов.

Ключевые слова: продуктивное долголетие, удой молока, стресс, воспроизводительная функция, наследуемость, генетические маркеры, свободные радикалы.

При интенсификации животноводства, особенно при промышленных технологиях содержания, животные лишены тесной взаимосвязи с естественной природной средой. Они не получают микроэлементы непосредственно из почвы, не подвергаются солнечной инсоляции, оказываются под воздействием дополнительных стрессов от скученности и работы механизмов. В результате наблюдается сокращение продолжительности жизни и хозяйственного использования поголовья. Удлинение сроков про- 
дуктивного использования животных становится важнейшей проблемой в разведении молочного и молочно-мясного скота, свиноводстве и других отраслях животноводства.

Целью настоящего обзора стало описание влияния различных генотипических и паратипических факторов на продолжительность жизни и продуктивное долголетие, а также анализ исследований по прогнозированию и поиску современных способов их продления у сельскохозяйственных животных.

В 1990-х годах продуктивное долголетие коров сибирского отродья черно-пестрой породы (удой за лактацию 3736-4122 кг, пожизненный удой 15500-17600 кг) при скрещивании с быками голштинской породы составляло 4,1-4,5 отела (1). При повышении удоев коров-первотелок время их использования в дойных стадах даже увеличивалось с 81,6 мес у коров с удоем 2501-3000 кг до 105,6 мес у коров, молочная продуктивность которых составляла 4501-5000 кг. Лучшими по продолжительности хозяйственного использования в холмогорской породе были коровы-первотелки с молочной продуктивностью не ниже 3501-4500 кг. Они эксплуатировались в дойных стадах не менее 94,8-104,4 мес (2).

В последние годы с увеличением продуктивности животных во многих хозяйствах Российской Федерации продолжительность использования коров стала снижаться до 2-3 лактаций (3). По данным В.И. Стрижакова (4), при продуктивности 5000-7000 кг срок использования коров составляет до трех отелов, при удое от 9000 до 10000 кг - два отела. Продолжительность использования коров в США, по данным J.R. Wright c соавт. (5), равна 2,8 лактации. По сведениям Е. Hare с соавт., для коров голштинской породы этот показатель составляет 2,8, айрширской - 2,9, гернзейской $-2,4$, джерзейской - 3,2 лактации. Средняя выживаемость коров ко 2-му отелу составляет $73 \%$, к 3-му - 50, к 4-му - 32, с 5-го по 8 -й отел - соответственно 19, 10, 5 и $2 \%$ (6). На английских молочных фермах из отобранных в 1-месячном возрасте голштино-фризских ремонтных телок $11 \%$ не доживает до 1-го отела. Из отелившихся животных 19 \% выбраковываются в период 1-й, 24 \% - в период 2-й лактации. Только $55 \%$ ремонтных телок успешно завершают 3-ю лактацию (7).

Н.А. Федосеева с соавт. (8) считают, что главной задачей повышения экономической эффективности разведения высокопродуктивных животных должно быть не столько увеличение удоев коров, сколько создание оптимальных условий для реализации уже созданного генетического потенциала молочной продуктивности и особенно повышения продуктивного долголетия. Проведенный анализ продуктивности выбывших голштинизированных коров холмогорской породы показал, что при среднегодовом удое 7400-7800 кг молока продуктивное долголетие составляет всего 3,3-3,8 отела. По мнению авторов, на этот показатель влияет множество факторов, к важнейшим из которых относятся стрессы, гиподинамия, дисбаланс питания, снижение адаптационных способностей организма, ведущие к нарушению воспроизводительной функции и рождению слабого потомства.

На важность удлинения срока использования высокопродуктивных коров еще в прошлом веке обращал особое внимание выдающийся селекционер, автор костромской породы С.И. Штейман, считавший, что это дает возможность увеличивать количество выдающегося племенного приплода и значительно снижать себестоимость всей продукции (9). На племзаводе «Караваево» некоторые коровы жили до 19-22-летнего возраста, их пожизненный удой составлял 98-103 т. Корова Послушница II дала за 300 сут 6-й лактации 14115 кг молока при содержании жира 3,92 \%. Ее 
рацион в сутки максимального суточного удоя (61 кг молока) состоял из концентрированных (58 \%), сочных (35\%) и грубых (7 \%) кормов. Корова-рекордистка по кличке Опытница прожила 19 лет. С.И. Штейман считал, что максимальный удой за лактацию можно получить в том случае, если корову хорошо подготовили в сухостойный период, создав в ее организме определенный запас питательных веществ (9, с. 98). Это способствует более равномерному покрытию расходов на молокообразование и позволяет избежать чрезмерного напряжения коровы в течение всей лактации.

Основные причины выбраковки коров в настоящее время - бесплодие, аборты, маститы, трудные отелы, рождение мелких или мертвых телят (10-13). Бесплодие особенно распространено среди животных, которые произвели более 11000 кг молока при первых отелах (14). Если условия жизни при первом отеле не соответствуют высокому производству молока, то продуктивная жизнь сокращается, а число отелов уменьшаетcя. J.M. Jaśkowski c coaвт. (15) считают, что высокий генетический потенциал молочной продуктивности коров влияет на снижение их фертильности. У них наблюдаются более длительный сервис-период, короткий цикл эструса и меньшая вероятность овуляции после отела. Ооциты коров с высоким генетическим потенциалом образуют меньшее количество бластоцист, чем у коров со средним потенциалом. Это ведет к бесплодию, послеродовым нарушениям.

Отелы, при которых животные нуждаются в помощи или хирургическом вмешательстве, увеличивают риск выбраковки на $18 \%$ по сравнению с отелами без посторонней помощи. Увеличение сложности отела оказывает болышее влияние на выбраковку в первые лактации, чем в последующие. Трудные отелы, главным образом первые, увеличивают затраты на амортизацию стада на 10 \% по сравнению с легкими (10). Выявлена статистически значимая связь между темпераментом и функциональной долговечностью коров (16). Очень нервные (чувствительные к стрессу) канадские коровы голштинской, айрширской и джерсейской пород были соответственно на 26, 23 и 46 \% более склонны к выбраковке, чем очень спокойные (стрессоустойчивые). Вероятность выбраковки очень тугодойных коров этих пород была на 36, 33 и 28 \% выше, чем среднетугодойных.

В последнее время в целях увеличения долголетия животных особое внимание уделяется некоторым экстерьерным статям. Установлено положительное влияние постановки задних конечностей, угла копыт и движения на продолжительность жизни. Коровы с лучшими показателями строения ног и копыт имеют больше шансов на длительное продуктивное использование. Между группами коров с наивысшей и низшей оценкой постановки тазовых конечностей разница по продолжительности хозяйственного использования составила 931 сут (17). В работе L. Zavadilová с соавт. (18) коровы с серповидными ногами имели более низкую долговечность, чем коровы с более прямыми ногами.

Установлено (19), что селекция на обильномолочность и удлинение лактации, вызывающие активацию лактационной доминанты, приводит к стрессам у животных. С увеличением молочной продуктивности происходит временное угасание половой доминанты, увеличивается продолжительность сервис-периода, снижается результативность искусственного осеменения и уменьшается продолжительность продуктивного использования (3). Так, по данным Г.А. Шаркаевой с соавт. (20), у коров импортной селекции с удоем 8271 кг за 1-ю лактацию сервис-период составил 194,6 сут против 114,9 сут у коров черно-пестрой породы с удоем 5688 кг. Причем сохранность коров импортной селекции до 3-й лактации состави- 
ла всего 38,6 \% против 54,5 \% коров местной селекции. Y. Schuermann с соавт. (21) считают долголетие ключевым компонентом устойчивого молочного животноводства. Высокопродуктивные молочные коровы часто страдают от дисфункции яичников и бесплодия, что приводит к снижению репродуктивной и продуктивной продолжительности жизни. Авторы объясняют бесплодие метаболическим стрессом в течение переходного периода (с 3-й по 12-ю нед после отела), когда отмечается повышение содержания холестерина, триглицеридов, общих желчных кислот и снижение концентрации глюкозы и глутатиона по сравнению с периодом до отела.

При повышении выхода молока снижается благополучие (animal welfare) коров в целом, рождаемость потомства, появляются проблемы с ногами и обменом веществ, снижается продолжительность жизни. Многие ученые считают благополучие животных экономически выгодным состоянием, которое служит показателем устойчивости системы и высокого качества продукции (22). В исследованиях Л.В. Ефимовой с соавт. (23), проведенных на большом поголовье, коэффициенты корреляции между удоем и воспроизводительной способностью у высокопродуктивных коров голштинской породы при беспривязном содержании на глубокой несменяемой подстилке (удой 7081 кг) были отрицательными ( $r$ от $-0,39$ до $-0,69$ у дочерей разных быков; уровень статистической значимости от $\mathrm{p}<0,05$ до $\mathrm{p}<0,001)$. У коров, содержавшихся беспривязно в боксах, при удое 6762 кг эти коэффициенты оказались положительными, хотя и незначительными $(r$ от 0,01 до 0,25$)$. То есть содержание в боксах, по-видимому, обеспечивало животным лучшее благополучие за счет меньшей подверженности стрессам и другим факторам среды (23). Исследования Y. Koketsu (24) свидетельствуют о том, что достижение долголетия и высокая репродуктивная способность животных в племенных стадах не противоречат друг другу. Эти показатели можно улучшать одновременно.

Л.В. Романенко с соавт. (25) и В.И. Волгина с соавт. (26) доказали, что для реализации генетического потенциала молочной продуктивности коров с удоем порядка 9000 кг молока и выше нужно оптимизировать энергетическое, протеиновое, углеводное и минерально-витаминное питание. Для оптимизации энергетического питания в стойловый период они рекомендуют увеличивать количество высокоэнергетических кормов в первую фазу лактации. Это способствует лучшей реализации генетического потенциала коров по удою в последующие месяцы.

В течение раннего послеродового периода ткани высокопродуктивных молочных коров подвергаются обширному катаболизму из-за отрицательного баланса питательных веществ. В этот период питательные вещества распределяются как в пользу лактации, так и на обеспечение жизнеспособности животного. Однако метаболические нарушения часто приводят к заболеваниям, которые резко снижают продуктивную и репродуктивную способность, а также иммунный статус (27). Недостаточное потребление питательных веществ и изменение кормления повышают риск развития метритов. Стратегия манипулирования здоровьем в дородовой и послеродовой периоды должна быть направлена на сведение к минимуму отрицательного баланса питательных веществ, улучшение гомеостаза и иммунитета за счет соответствующей диеты. Добавки ненасыщенных жирных кислот семейств n-3 и n-6 обычно улучшают фертильность, если не мешают метаболизму микроорганизмов рубца.

Существенное влияние на состояние здоровья, воспроизводительную функцию, продуктивность коров и качество молока оказывает применение минеральных кормов, регулирующих кислотно-щелочное соотно- 
шение, особенно кальция (28). В первые недели после отела, когда снижена поедаемость основных кормов, корове недостаточно того количества кальция, который она способна потребить. При кормлении сухостойных коров специальными добавками, создающими кислую среду, решаются проблемы улучшения воспроизводства, повышения продуктивности в течение лактационного периода, снижения затрат на ветеринарные препараты. Жизненно важную роль в кальциевом обмене, в формировании костей и включении этого элемента в структуру скелета играет витамин Е. Кальциевые соли полиненасыщенных жирных кислот используются в мясном скотоводстве для повышения репродуктивной способности коров (29).

Негативные последствия для репродуктивной функции и длительности продуктивного использования животных наблюдаются и в свиноводстве при увеличении молочной продукции свиноматок из-за большого размера помета, приводящего к чрезмерной мобилизации запасов тела во время лактации. Продолжительность жизни и продуктивного использования свиноматок также становится экономической проблемой, особенно при высокой продуктивности. Эти показатели зависят от возраста при первом опоросе, числа опоросов за период использования, продолжительности периода между отъемом и охотой, многоплодия, числа мертворожденных поросят и поросят, родившихся за период жизни свиноматки, скорости роста и выживаемости поросят-сосунов. Чем выше многоплодие, меньше мертворожденных поросят и выше масса гнезда в 21-суточном возрасте, тем ниже вероятность их выбраковки (30).

В свиноводстве наблюдается особенное отношение к подготовке маток в сухостойный период и в течение супоросности, чтобы у свиноматки было достаточно молока для кормления поросят при сохранении ее продолжительного использования. В условиях свинокомплексов принято получать от матки 4,5 опороса за период использования. Однако это не всегда достигается, хотя от некоторых маток получают по 11-12 опоросов. Наиболее частыми причинами выбраковки свиноматок, как и в молочном скотоводстве, становятся репродуктивные проблемы (40-51 \%), проблемы с ногами (23 -29 \%) и смертность (15-19 \%) (31). Эксперименты показали, что отбор свинок от высокопродуктивных и приспособленных маток, выдержавших в условиях комплекса 5 и более опоросов, и хряков, содержавшихся без выгула не менее 2 лет, может быть эффективен, но при содержании в течение нескольких месяцев до осеменения с включением моциона (32). Условия содержания и кормления влияют на упитанность свинок при первом опоросе, что отражается на состоянии тела, крепости ног и долголетии. Эти показатели улучшаются при выращивании свинок на напольных покрытиях и подстилке, способствующих развитию здоровых ног, и рационах, ограничивающих потерю живой массы во время лактации (33).

Главный лимитирующий фактор многоплодия свиноматок - эмбриональные потери в течение первых 2-3 нед супоросности (34). Воспроизводительные качества свиноматок в значительной степени зависят от содержания протеина и лизина в рационе. Низкое потребление этих веществ ослабляет развитие фолликулов, уменьшает их способность поддерживать созревание ооцитов, становится основной причиной выбытия свиноматок из-за агалактии, приводит к снижению молочности из-за недостаточного накопления питательных веществ в организме. Во время супоросности свиноматки нуждаются в значительных количествах минеральных веществ (Ca, P, Fe, $\mathrm{Zn}, \mathrm{Mn}$, Se и др.), которые участвуют в строительстве костей эмбрионов, синтезе молока. Б. Клоуз (35) считает, что содержание этих минеральных веществ в рационе следует увеличивать при каж- 
дой последующей супоросности на $5 \%$. Чтобы улучшать экономические показатели свиноводства, нужно сокращать время между отъемом и охотой. На этот период, а вместе с тем и на длительность всего продуктивного использования свиноматок влияют такие факторы, как сроки и продолжительность овуляции, правильность определения охоты и техники осеменения, качество семени, смертность эмбрионов, упитанность, иммунный статус (36). Срок от отъема до осеменения определяет и многоплодие свиноматок. Выявлено, что многоплодие и масса гнезда поросят при отъеме, а также интервал между отъемом и охотой выше у свиноматок с более поздними сроками полового созревания (223-226 против 185 сут.).

Селекция животных с помощью статистических методов недостаточно эффективна из-за низкой наследуемости, относительно позднего проявления признака или его проявления только под действием определенных факторов, наличия скрытых носителей нежелательных признаков, болезней. Коэффициент наследуемости выживаемости у телок и коров голштино-фризской породы в Великобритании, по данным T. Pritchard c соавт. (37), составила 0,01-0,06. Наследуемость продолжительности хозяйственного использования коров мясных пород невелика $\left(\mathrm{h}^{2}=0,14\right)$, поэтому считается, что генетическое улучшение долголетия затруднено (38). Коэффициент наследуемости продолжительности жизни и репродуктивных признаков у свиней варьирует от 0,14 до 0,17 (39). Для наследуемости интервала между отъемом и первой охотой у свиноматок после опороса этот показатель составляет 0,17-0,18. Коэффициент наследуемости общего количества поросят в гнезде, живорожденных поросят, числа мертворожденных поросят равняется соответственно 0,10; 0,08 и 0,19 (40).

Современное развитие науки позволяет управлять селекцией не только через оценку племенной ценности статистическими методами, но и на геномном уровне. Генетика и селекция животных развиваются на основе базовой теории генетики популяции - от разработки индексов отбора и создания сложных систем генетического прогнозирования до продвижения в сторону разработки систем точного управления геномом. На основании получаемой информации можно вести генетический отбор и управлять конкретными генотипами на ранней стадии жизни животного (41). От определения индекса племенной ценности посредством метода наилучшего линейного несмещенного прогноза BLUP (best linear unbiased predictor), базирующегося на взаимодействии генотипа и среды (коэффициент наследуемости), переходят к маркер-ориентированной селекции (markerassisted selection, MAS) по определенным генам, контролирующим хозяйственно полезные признаки, независимо от степени их наследования.

Так, в качестве генетического маркера продолжительности продуктивной жизни крупного рогатого скота, содержания жира и молочной продуктивности идентифицирован ген DGAT1, расположенный в 14-й хромосоме (ВТА14) (42). У кроссбредных коров на 4-й, 5-й, 15-й и 19-й хромосомах обнаружены однонуклеотидные полиморфизмы (single nucleotide polymorphism, SNP), связанные с репродуктивным долголетием, которые можно использовать для увеличения длительности жизни животных (43). У североамериканского молочного скота при идентификации геномных областей подтвердились результаты предыдущих исследований и были обнаружены новые участки, связанных с долголетием, устойчивостью лактации, воспроизводительной функцией и прибылью (44). Q. Zhang с соавт. (45) определили два важных геномных региона, расположенных на хромосомах 6-й (META-CHR6-88MB) и 18-й (META-CHR18-58MB), которые связаны с долголетием. Ген NPFFR2 ранее был идентифицирован как 
ген-кандидат по устойчивости к маститу, маркер META-CHR18-58MB связан с трудностями отела. Связь полиморфных вариантов ДНК с признаками молочной продуктивности у крупного рогатого скота подробно обсуждается Н.С. Юдиным с соавт. (46).

Для свиней найдено около 30000 генов (47), которые можно задействовать при геномной селекции. Она особенно эффективна по признакам, проявляющимся на поздних стадиях онтогенеза (продолжительность жизни) или имеющих низкую наследуемость (воспроизводительная способность), а также по устойчивости к болезням и стрессам $(41,48)$. В настоящее время особое значение приобретают гены-кандидаты, связанные с репродуктивными особенностями свиней ( $E S R$ и $P R L R$ ) (49), характеристиками строения ног, долговечностью свиноматки (50-52). Найдены генетические маркеры, позволяющие улучшать показатели молочной продуктивности, которые связаны с репродуктивными качествами и продолжительностью жизни свиноматок (53).

Установлено, что продолжительность использования свиноматок в значительной степени зависит от нескольких генов, влияющих на эти процессы. Так, генетические маркеры carnitine O-palmitoyltransferase (CPT1A) и C-C chemokine receptor $(C C R 7)$ были достоверно $(\mathrm{p}<0,05)$ связаны по меньшей мере с одним репродуктивным признаком. Эти результаты показывают, что молекулярные маркеры следует рассматривать для использования в селекции с целью улучшения продолжительности использования свиноматок $(54,55)$.

Можно полагать, что геномная селекция на продолжительность жизни и хозяйственного использования животных, а также на продуктивность будет более эффективной. В этом случае геном тестируется с использованием чипов (матриц) сразу по большому количеству однонуклеотидных маркеров, так называемых снипов (SNP), покрывающих весь геном и связанных с локусами количественных признаков (quantitative trait locus, QTL), что дает возможность определять генотипы с желательным проявлением продуктивных признаков и оценивать племенные качества животного. Геномная селекция позволяет расшифровывать генотип уже при рождении и отбирать для разведения лучших животных, что увеличивает точность и надежность оценки племенных свиней, значительно ускоряет селекционный процесс.

Революционизирующим становятся поиск и использование в селекции маркеров ядерной и митохондриальной ДНК. Однако следует иметь в виду, что генетические маркеры могут указывать на местоположение определенных генетических факторов, связанных с признаками долголетия или продуктивности, в хромосомах животных, быть средством раннего прогнозирования признаков продуктивности и ускоренной селекции, но не вскрывают биохимических и биофизических процессов, протекающих в организме при их фенотипическом проявлении или взаимодействии друг с другом. В значительной степени их проявление зависит от факторов окружающей среды, в том числе от различных стрессовых раздражений.

Теории старения организмов разделяют на два типа - генетические и свободно-радикальные (56). Процесс старения - этой переменное, стохастическое и плейотропное явление, которое регулируется различными экологическими и генетическими факторами (57). В стареющих клетках снижается активность фермента теломеразы, что вызывает укорочение концевых участков хромосом - теломер и не обеспечивает сохранение свойств ДНК в последовательных поколениях клеточных делений (58). Укорочение теломер происходит во всех соматических клетках организма 
при многих заболеваниях (59). Согласно свободно-радикальной теории старения, в процессе жизнедеятельности в цитоплазме появляются так называемые свободные радикалы, которые играют ключевую роль в репродуктивной функции млекопитающих, при развитии фолликулов, в процессе созревания ооцитов и сперматозоидов, их капацитации. Возникновение радикалов зависит от многих факторов, в том числе от состава корма (60), условий содержания, генетических особенностей животных (61). В опытах на мышах показано, что окислительный процесс, который наблюдается в сыворотке крови, яичниках и яйцеклетках и вызывается стрессами животных, вносит значительный вред развитию ооцитов (62). В сперматозоидах, характеризующихся чрезвычайно высокой скоростью метаболизма, образуется особенно много свободных радикалов $(63,64)$. Существуют специфические ферментные поглотители реактивных форм кислорода - глутатионпероксидаза, каталаза, супероксиддисмутаза (65), которые превращают активные формы кислорода в безвредные молекулы и играют огромную роль при развитии фолликулов и процессе созревания ооцитов $(61,65,66)$. Каталаза испытана учеными для улучшения качества спермы при ее замораживании $(66,67)$. Ведущая роль в молекулярных механизмах антиоксидантной защиты и приведение концентрации свободных радикалов к физиологической норме принадлежит тиоловым соединениям, у которых имеются сульфгидрильные группы (SH-группы), проявляющие высокую реакционную способность $(68,69)$. Определенные

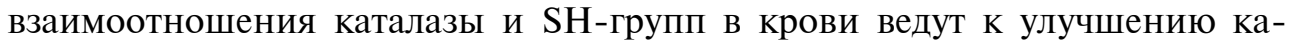
пацитации сперматозоидов и тем самым - к лучшему оплодотворению яйцеклеток $(70,71)$.

Новейшие представления об особенностях процессов с участием свободно-радикальных частиц и генерацией электронно-возбужденных состояний в онтогенезе основываются на принципах теоретической биологии, сформулированных еще в 1930-е годы Э.С. Бауэром (72). Согласно ним, живая система извлекает вещества и энергию из среды благодаря более высокому термодинамическому (биофизическому) потенциалу. Для этого необходим определенный внешний импульс (сигнал), то есть стрессовый раздражитель в пределах физиологической нормы (59). Организм животных, особенно из воспроизводительных групп, должен не просто находиться в благоприятных условиях, но и иметь систематические оптимальные нагрузки, требующие мобилизации нейроэндокринных систем. Экспериментами и практикой показано положительное действие принудительного движения на состояние здоровья и спермопродукцию производителей, на развитие ремонтного молодняка, продуктивность маточного поголовья, их жизнеспособность.

Таким образом, для увеличения сроков продолжительности использования и долголетия сельскохозяйственных животных при сочетании с высокой продуктивностью и приспособленностью к различным, в том числе неблагоприятным, факторам внешней среды, следует использовать набор приемов. В первую очередь, это полноценное кормление и создание благоприятных условий содержания, способствующих получению полезной продукции. При этом следует учитывать необходимость воздействия на животных определенными факторами внешней среды (стрессовые воздействия) в пределах их физиологической нормы, что стимулирует работу биохимических систем, продукцию активных форм кислорода, вызывает электронновозбужденные состояния в клетках и тем самым повышает биофизический потенциал организма. Во-вторых, необходимо создание стад (пород, типов) животных с высоким генетическим потенциалом продуктивности с исполь- 


\section{ЛИТЕРАТУРА}

1. Клименок И.И., Рогальский Г.Л., Майле А.В. Взаимосвязь воспроизводительной способности с продуктивным долголетием у голштинизированного скота Сибири. Сибирский вестник сельскохозяйственной науки, 2001, 3-4: 75-80.

2. Павлюхин А.М., Стародумов И.М., Туников Г.М. Продолжительность хозяйственного использования коров в зависимости от их молочной продуктивности по первой лактации. Мат. Межд. науч.-практ. конф. молодых ученых и специалистов «Вклад молодых ученых в развитие аграрной науки ХХІ века». Рязань, 2004: 141-144.

3. Сельцов В.И., Молчанова Н.Н. Влияние методов разведения на продуктивное долголетие и пожизненную продуктивность коров. Зоотехния, 2013, 9: 2-4.

4. Стрижаков В.И. Анализ причин выбраковки коров в АО «Омский бекон» Омской области. В сб.: Производство продуктов животноводства в Западной Сибири. Омск, 1999: 27-28.

5. Wright J.R., VanRaden P.M. Genetic evaluation of dairy cow livability. Journal of Animal Science, 2016, 94(suppl. 5): 178-178 (doi: 10.2527/jam2016-0368).

6. Hare E., Norman H.D., Wright J.R. Survival rates and productive herd life of dairy cattle in the United States. Journal of Dairy Science, 2006, 89(9): 3713-3720 (doi: 10.3168/jds.S00220302(06)72412-2).

7. Brickell J.S, Wathes D.C. A descriptive study of the survival of Holstein-Friesian heifers through to third calving on English dairy farms. Journal of Dairy Science, 2011, 94(4): 18311838 (doi: $10.3168 /$ jds.2010-3710).

8. Федосеева Н.А., Киселев В.Л., Новикова Н.Н., Иванова Н.И., Громов Л.С. Влияние живой массы и возраста плодотворного осеменения телок холмогорской породы на долголетие коров при разных условиях содержания. Зоотехния, 2016, 10: 29-31.

9. Штейман С.И. Как создано рекордное караваевское стадо. М., 1948.

10. López de Maturana E., Ugarte E., González-Recio O. Impact of calving ease on functional longevity and herd amortization costs in Basque Holsteins using survival analysis. Journal of Dairy Science, 2007, 90(9): 4451-4457 (doi: 10.3168/jds.2006-734).

11. Le Cozler Y., Lollivier V., Lacasse P., Disenhaus C. Rearing strategy and optimizing first-calving targets in dairy heifers: a review. Animal, 2008, 2(9): 1393-1404 (doi: 10.1017/S1751731108002498).

12. Sewalem A., Miglior F., Kistemaker G.J., Sullivan P., Van Doormaal B.J. Relationship between reproduction traits and functional longevity in canadian dairy cattle. Journal of Dairy Science, 2008, 91(4): 1660-1668 (doi: 10.3168/jds.2007-0178).

13. Bell M.J., Wall E., Russell G., Roberts D.J., Simm G. Risk factors for culling in HolsteinFriesian dairy cows. Veterinary Record, 2010, 167: 238-240 (doi: 10.1136/vr.c4267).

14. Sawa A., Bogucki M. Longevity of cows depending on their first lactation yield and herd production level. Annals of Animal Science, 2017, 17(4): 1171-1183 (doi: 10.1515/aoas-2016-0096).

15. Jaśkowski J.M., Olechnowicz J., Nowak W. Several reasons for decreasing fertility in dairy cows. Med. Weter., 2006, 62: 385-389.

16. Sewalem A., Miglior F., Kistemake G.J. Analysis of the relationship between workability traits and functional longevity in Canadian dairy breeds. Journal of Dairy Science, 2010, 93(9): 43594365 (doi: 10.3168/jds.2009-2969).

17. Хмельничий Л.М., Вечерка В.В. Влияние линейных признаков типа, характеризующих состояние конечностей, на длительность использования коров украинской чернопестрой молочной породы. Генетика и разведение животных, 2015, 2: 36-39.

18. Zavadilová L., E. Němcová, M. Štípková. Effect of type traits on functional longevity of Czech Holstein cows estimated from a Cox proportional hazards model. Journal of Dairy Science, 2011, 94(8): 4090-4099 (doi: 10.3168/jds.2010-3684).

19. Абилов А.И., Виноградова И.В., Жаворонкова Н.В., Виноградов В.Н. Влияние различных стресс-факторов на воспроизводительную способность голштинизированных коров. Зоотехния, 2015, 11: 21-25.

20. Шаркаева Г.А., Шаркаев В.И. Сравнительные результаты использования импортного и отечественного скота. Зоотехния, 2016, 2: 20-21.

21. Schuermann Y., St-Yves A., Dicks N., Bohrer R. C., Mondadori R., Welsford G., Boyer V., Taibi M., Higginson V., Hartley S., Madogwe E., Bordignon V., Baurhoo B., Duggavathi R. The transition cow: may the odds be ever in her favor. Journal of Animal Science, 2016, 94(suppl. 5): 234-235 (doi: 10.2527/jam2016-0488).

22. Oltenacu P.A., Broom D.M. The impact of genetic selection for increased milk yield on the welfare of dairy cows. Animal Welfare, 2010, 19: 39-49.

23. Ефимова Л.В., Зазнобина Т.В. Влияние генетических и технологических факторов на продуктивные качества коров. Вестник АПК Ставрополья, 2017, 4(28): 58-63.

24. Koketsu Y. Longevity and efficiency associated with age structures of female pigs and herd management in commercial breeding herds. Journal of Animal Science, 2007, 85(4): 1086-1091 
(doi: 10.2527/jas.2006-493).

25. Романенко Л.В., Волгин В.И., Федорова З.Л. Стратегия питания высокопродуктивных голштинизированных коров черно-пестрой породы. Молочное и мясное скотоводство, 2014, 6: 34-36.

26. Волгин В.И., Бибикова А.С., Романенко Л.В., Морозов Н.Н. Оптимизация энергетического питания высокопродуктивных коров черно-пестрой породы. В сб. науч. тр.: Селекиионно-генетические методы повышения продуктивности сельскохозяйственных жсивотных. СПб, 2004: 88-92.

27. Bisinotto R.S., Greco L.F., Ribeiro E.S., Martinez N., Lima F.S., Staples C.R., Thatcher W.W., Santos1 J.E.P. Influences of nutrition and metabolism on fertility of dairy cows. Animal Reproduction, 2012, 9(3): 260-272.

28. Лашкина Т. Пусть долго живет корова! Животноводство России, 2006, 10: 54-55.

29. Lopes C.N., Cooke R.F., Reis M.M., Peres R.F.G., Vasconcelos J.L.M. Strategic supplementation of calcium salts of polyunsaturated fatty acids to enhance reproductive performance of Bos indicus beef cows. Journal of Animal Science, 2011, 89(10): 3116-3124 (doi: 10.2527/jas.2011-3909).

30. Hoge M.D., Bates R.O. Developmental factors that influence sow longevity. Journal of Animal Science, 2011, 89(4): 1238-1245 (doi: 10.2527/jas.2010-3175).

31. Balogh P., Kapelański W., Jankowiak H., Nagy L., Kovacs S., Huzsvai L., Popp J., Posta J., Soltesz A. The productive lifetime of sows on two farms from the aspect of reasons for culling. Annals of Animal Science, 2015, 15(3): 747-758 (doi: 10.1515/aoas-2015-0020).

32. Бекенев В.А. Технология разведения и содержания свиней. СПб, 2012.

33. Gill P. Nutritional management of the gilt for lifetime productivity - feeding for fitness or fatness? Proc. London Swine Conference. London, 2007: 83-99.

34. Geisert D., Schmitt R.A.M. Early embryonic survival in the pig: can it be improved? Journal of Animal Science, 2002, 80: 54-65.

35. Клоуз Б. Стратегия увеличения продуктивного долголетия свиноматок. Промышленное и племенное свиноводство, 2007, 3: 18-20.

36. Клоуз Б. Стратегия увеличения продуктивного долголетия свиноматок. Промышленное $и$ племенное свиноводство, 2007, 2: 32.

37. Pritchard T., Coffey M., Mrode R., Wall E. Understanding the genetics of survival in dairy cows. Journal of Dairy Science, 2013, 96(5): 3296 (doi: 10.3168/jds.2012-6219).

38. Rogers P.L., Gaskins C.T., Johnson K.A., MacNeil M.D. Evaluating longevity of composite beef females using survival analysis techniques. Journal of Animal Science, 2004, 82(3): 860-866 (doi: $10.2527 / 2004.823860 x$ ).

39. Nikkilä M.T., Stalder K.J., Mote B.E., Rothschild M.F., Gunsett F.C., Johnson A.K., Karriker L.A., Boggess M.V., Serenius T.V. Genetic associations for gilt growth, compositional, and structural soundness traits with sow longevity and lifetime reproductive performance. Journal of Animal Science, 2013, 91(4): 1570-1579 (doi: 10.2527/jas.2012-5723).

40. Canario L., Cantoni E., Le Bihan E., Caritez J.C., Billon Y., Bidanel J.P., Foulley J.L. Between-breed variability of stillbirth and its relationship with sow and piglet characteristics. Journal of Animal Science, 2006, 84(12): 3185-3196 (doi: 10.2527/jas.2005-775).

41. Green R.D. ASAS centennial paper: future needs in animal breeding and genetics. Journal of Animal Science, 2009, 87(2): 793-800 (doi: 10.2527/jas.2008-1406).

42. Kaupe B., Brandt H., Prinzenberg E.-M., Erhardt G. Joint analysis of the influence of CYP11B1 and DGAT1 genetic variation on milk production, somatic cell score, conformation, reproduction, and productive lifespan in German Holstein cattle. Journal of Animal Science, 2007, 85(1): 11-21 (doi: 10.2527/jas.2005-753).

43. Engle B.N., Herring A.D., Sawyer J.E., Riley D.G., Sanders J.O., Gill C.A. Genome-wide association study for stayability measures in Nellore-Angus crossbred cows. Journal of Animal Science, 2016, 94(supp. 4): 142 (doi: 10.2527/jas2016.94supplement4142x).

44. Nayeri S., Sargolzaei M., Abo-Ismail M.K., Miller S., Schenkel F., Moore S.S., Stothard P. Genome-wide association study for lactation persistency, female fertility, longevity, and lifetime profit index traits in Holstein dairy cattle. Journal of Dairy Science, 2016, 100(2): 1246-1258 (doi: 10.3168/jds.2016-11770).

45. Zhang Q., Guldbrandtsen B., Thomasen J.R., Lund M.S., Sahana G. Genome-wide association study for longevity with whole-genome sequencing in 3 cattle breeds. Journal of Dairy Science, 2016, 99(9): 7289-7298 (doi: 10.3168/jds.2015-10697).

46. Юдин Н.С., Воевода М.И. Молекулярно-генетические маркеры экономически важных признаков у молочного скота. Генетика, 2015, 51(5): 600-612 (doi: 10.7868/S0016675815050082).

47. van der Steen H.A.M., Prall G.F.W., Plastow G.S. Application of genomics to the pork industry. Journal of Animal Science, 2005, 83(suppl 13): E1-E8 (doi: 10.2527/2005.8313_supplE1x).

48. Cleveland M.A., Forni S., Garrick D.J., Deeb N. Prediction of genomic breeding values in a commercial pig population. Proc. 9th World Congress on Genetics Applied to Livestock Production. Leipzig, 2010: 0266.

49. Rempel L.A., Nonneman D.J., Wise T.H., Erkens T., Peelman L.J., Rohrer G.A. Association analyses of candidate single nucleotide polymorphisms on reproductive traits in swine. Journal of Animal Science, 2010, 88(1): 1-15 (doi: 10.2527/jas.2009-1985). 
50. Onteru S.K., Fan B., Nikkilä M.T., Garrick D.J., Stalder K.J., Rothschild M.F. Whole-genome association analyses for lifetime reproductive traits in the pig. Journal of Animal Science, 2011, 89(4): 988-995 (doi: 10.2527/jas.2010-3236).

51. Serenius T., Stalder K.J. Selection for sow longevity. Journal of Animal Science, 2006, 84(suppl. 13): E166-E171 (doi: 10.2527/2006.8413_supple166x).

52. Sironen A.I., Uimari P., Serenius T., Mote B., Rothschild M., Vilkki J. Effect of polymorphisms in candidate genes on reproduction traits in Finnish pig populations. Journal of Animal Science, 2010, 88(3): 821-827 (doi: 10.2527/jas.2009-2426).

53. Thekkoot D.M., Young J.M., Rothschild M.F. Dekkers J.C.M. Genomewide association analysis of sow lactation performance traits in lines of Yorkshire pigs divergently selected for residual feed intake during grow finishphase. Journal of Animal Science, 2016, 94(6): 2317-2331 (doi: 10.2527/jas.2015-0258).

54. Rohrer G.A., Cross A.J., Lents C.A., Miles J.R., Nonneman D.J., Rempel L.A. Genetic improvement of sow lifetime productivity. Journal of Animal Science, 2017, 95(suppl. 2): 11-12 (doi: 10.2527/asasmw.2017.026).

55. Mote B.E., Koehler K.J., Mabry J.W., Stalder K.J., Rothschild M.F. Identification of genetic markers for productive life in commercial sows. Journal of Animal Science, 2009, 87(7): $2187-$ 2195 (doi: 10.2527/jas.2008-1017).

56. Воейков В.Л. Био-физико-химические аспекты старения и долголетия. Усnехи геронтологии, 2002, 9: 54-66.

57. Wnuk M., Bugno-Poniewierska M., Lewińska A., Oklejewicz B., Ząbek T., Słota E. Aging process in chromatin of animals. Annals of Animal Science, 2012, 12(3): 301-309 (doi: 10.2478/v10220-012-0025-3).

58. Gilley D., Herbert B.S., Huda N., Tanaka H., Reed T. Factors impacting human telomere homeostasis and age-related disease. Mechanisms of Ageing and Development, 2008, 129(1-2): $27-$ 34 (doi: 10.1016/j.mad.2007.10.010).

59. Борисов В.И., Кожевников В.С., Сенюков В.В., Сизиков А.Э., Коненкова Л.П., Герцог О.А., Козлов В.А. Укорочение длины теломер моноцитов при ревматоидном артрите. Медицинская иммунология, 2006, 1: 87-90 (doi: 10.15789/1563-0625-2006-1-87-90).

60. Boler D.D., Fernández-Dueñas D.M., Kutzler L.W., Zhao J., Harrell R.J., Campion D.R., McKeith F.K., Killefer J., Dilger A.C. Effects of oxidized corn oil and a synthetic antioxidant blend on performance, oxidative status of tissues, and fresh meat quality in finishing barrows. Journal of Animal Science, 2012, 90(13): 5159-5169 (doi: 10.2527/jas.2012-5266).

61. Cambi M., Tamburrino L., Marchiani S., Olivito B., Azzari C., Forti G., Baldi E., Muratori M. Development of a specific method to evaluate 8-hydroxy,2-deoxyguanosine in sperm nuclei: relationship with semen quality in a cohort of 94 subjects. Reproduction, 2013, 145(3): 227-235 (doi: 10.1530/REP-12-0404).

62. Lian H.Y., Gao Y., Jiao G.Z., Sun M.J., Wu X.F., Wang T.Y., Li H., Tan J.H. Antioxidant supplementation overcomes the deleterious effects of maternal restraint stress-induced oxidative stress on mouse oocytes. Reproduction, 2013, 146(6): 559-568 (doi: 10.1530/REP-13-0268).

63. Ribou A.C., Reinhardt K. Reduced metabolic rate and oxygen radicals production in stored insect sperm. Proceedings the Royal Society B. Biological Science, 2012, 279(1736): 2196-2203 (doi: 10.1098/rspb.2011.2422).

64. Sullivan R., Saez F. Epididymosomes, prostasomes, and liposomes: their roles in mammalian male reproductive physiology. Reproduction, 2013, 146(1): R21-R35 (doi: 10.1530/REP-13-0058).

65. Chabory E., Damon C., Lenoir A., Henry-Berger J., Vernet P., Cadet R., Saez F., Drevet J.R. Mammalian glutathione peroxidases control acquisition and maintenance of spermatozoa integrity. Journal of Animal Science, 2010, 88(4): 1321-1331 (doi: 10.2527/jas.2009-2583).

66. Wu Q.Q., Lam C., Poljak D., Van Deventer G.M., Bradley C.P., Combelles C.M.H. Characterization of the catalase and glutathione peroxidase-1 antioxidant system during bovine folliculogenesis. Biology of Reproduction, 2009, 81(suppl. 1): 581 (doi: 10.1093/biolreprod/81.s1.581).

67. Eidan S.M. Effect on post-cryopreserved semen characteristics of Holstein bulls of adding combinations of vitamin $\mathrm{C}$ and either catalase or reduced glutathione to Tris extender. Animal Reproduction Science, 2016, 167: 1-7 (doi: 10.1016/j.anireprosci.2016.01.014).

68. Полушин Ю.С., Левшанков А.И., Лахин Р.Е., Пащинин А.Н., Безрукова Е.В., Пискунович А.Л., Костючек Д.Ф., Белозерова А.К., Гайдуков С.Н., Шапкайц В.А., Белозерова Л.А., Краснов Н.В. Перспективы использования анализатора тиоловых антиоксидантов в клинической практике для оценки неспецифической резистентности организма при различных критических состояния и для прогнозирования акушерских осложнений. Научное приборостроение, 2013, 23(3): 5-12.

69. Coy P., Grullon L., Canovas S., Romar R., Matas C., Aviles M. Hardening of the zona pellucida of unfertilized eggs can reduce polyspermic fertilization in the pig and cow. Reproduction, 2008, 135(1): 19-27 (doi: 10.1530/REP-07-0280).

70. Leahy T., Gadella B.M. Sperm surface changes and physiological consequences induced by sperm handling and storage. Reproduction, 2011, 142(6): 759-778 (doi: 10.1530/REP-11-0310).

71. Aitken R.J., Curry B.J. Redox regulation of human sperm function: from the physiological control of sperm capacitation to the etiology of infertility and DNA damage in the germ line. Anti- 
oxidants \& Redox Signaling, 2011, 14(3): 367-381 (doi: 10.1089/ars.2010.3186).

72. Бауэр Э.С. Теоретическая биология. М.-Л., 1935.

ФГБУН Сибирский федеральный научный центр агробиотехнологий РАН,

Поступила в редакцию

Сибирский научно-исследовательский

23 июля 2018 года

и проектно-технологический институт животноводства,

630501 Россия, Новосибирская обл., Новосибирский р-н,

р.п. Краснообск, СФНЦА РАН, а/я 463,

e-mail: bekenev@ngs.ru $₫$, sibniptij@ngs.ru

Sel'skokhozyaistvennaya biologiya [Agricultural Biology], 2019, V. 54, № 4, pp. 655-666

\section{PRODUCTIVE LONGEVITY OF ANIMALS, METHODS OF ITS PREDICTION AND EXTENSION} (review)

\section{V.A. Bekenev}

Siberian Federal Scientific Center of Agro-BioTechnologies RAS, Siberian Research and Technological Institute of Animal Husbandry, PO box 463, r.p. Krasnoobsk, Novosibirskii Region, Novosibirsk Province, 630501 Russia, e-mail bekenev@ngs.ru (凹 corresponding author), sibniptij@ngs.ru

ORCID:

Bekenev V.A. orcid.org/0000-0003-4663-2217

The author declares no conflict of interests

Received July 23, 2018

doi: 10.15389/agrobiology.2019.4.655eng

\section{Abstract}

Lengthening the terms of the productive use of animals is the most important problem in the cultivation of dairy and dairy and beef cattle, pig breeding and other branches of animal husbandry. The aim of this work was to review the influence of various genotypic and paratypic factors on life expectancy, productive longevity of farm animals, as well as analysis of studies to find modern ways of predicting and prolonging them. It was shown that with an increase in milk yield for lactation from $2500-3000 \mathrm{~kg}$ to $10000 \mathrm{~kg}$ of milk, the duration of productive use of cows decreases from 7-9 to 2-3 lactations, which increases the cost of milk production (I.I. Klimenok et al., 2001; J.R. Wright et al., 2016 et al.). An increase in milk productivity is accompanied by a decrease in reproductive function: the service period is prolonged, animal fertility decreases due to stress resulting from activation of the lactational dominant (A.I. Abilov et al., 2013; Y.S. Schuermann et al., 2016 , etc.) To improve reproductive functions, duration of use, it is recommended to use special mineral-vitamin supplements (L.V. Romanenko et al., 2014; B. Close, 2007). Animal welfare is considered as an indicator of the stability of the system and is considered economically profitable (P.A. Oltenacu et al., 2010; L.V. Efimova et al., 2017). The duration of the productive use of sows, depending on the number of farrowing during use, fertility, survival of piglets and other factors is 3-4 farrowing instead of 4.5 in accordance with the accepted norm, which also affects economic indicators (M.D. Hoge et al., 2011). The indicators of heritability of signs of longevity in cattle and pigs are given (L. Canario et al., 2006), various feeding methods, breeding techniques, including the use of genetic markers to lengthen the economic use of animals. (C.N. Lopes et al., 2011; A.I. Sironen et al., 2010 et al.). Molecular markers related to the reproductive characteristics and duration of use of animals are given, which should also be used in genomic selection (N.S. Yudin et al., 2015; Q. Zhang et al., 2017). The theoretical provisions on the causes of aging, the influence of various stressors arising as a result of peroxide and antioxidant processes in the body are considered (E.S. Bauer, 1935; V.L. Voeikov, 2002). The role of reactive oxygen species, free radicals, and antioxidants of different nature on the reproductive function and viability of animals under stressful effects of different strengths is discussed (D.D. Boler et al., 2012; M. Sajeda Eidan, 2016). Thus, to increase the duration of the use and longevity of farm animals, combined with high productivity and adaptability to various, including adverse environmental factors, methods should be used that add up to several positions. It is necessary to develop and use proper feeding techniques that optimize the energy balance during all periods of the reproductive cycle, create favorable conditions for keeping animals, providing for exposure to certain stimulating factors that increase the biophysical potential of the body, affecting the functioning of biochemical systems. One should use the latest methods for predicting the level of free-radical oxidation of animal tissue lipids, which affect the manifestation of oestrus, oocyte and sperm viability, and the use of antioxidants with feed additives to balance oxidative and antioxidative processes. One more approach is to create herds (breeds, types) of animals with a high genetic potential for productivity and stress resistance using the most effective selection methods, genetic markers, genetic and mathematical models, and genetic engineering methods.

Keywords: productive longevity, milk yield, stress, reproductive function, heritability, genetic markers, free radicals. 